\title{
Human cervical epithelial cells that express HLA- DR associated with viral infection and activated mononuclear cell infiltrate
}

\author{
S Fais, F Delle Fratte, F Mancini, V Cioni, M Guadagno, G Vetrano, F Pallone
}

\begin{abstract}
The association between the expression of HLA-DR antigens on cervical epithelium and the local immune state of activation in colposcopically obtained biopsy specimens from patients with histologically documented wart virus infection was investigated. In normal cervical epithelium no HLA-DR staining was detected. No or few IL-2R positive cells were found in the contiguous sections. HLA-DR was expressed by epithelial cells in six out of the 14 samples of wart virus infection. The pattern of fluorescence was focal, but strong and diffuse, to the whole epithelial layer. In the six samples with HLA-DR positive epithelium the numbers of $I L-2 R$ positive cells in the lamina propria were strongly increased, ranging between 75 and $90 \%$. HLA-DR expression by cervical epithelium was observed in only two of 12 samples from patients with mixed epithelial non-virus related abnormalities. No increase in the numbers of IL-2R positive cells was observed in this group of patients. Additionally, no significant differences in terms of $T$ lymphocyte infiltrate were found among the three groups. The results indicate that wart virus infection is associated with enhanced HLA-DR epithelial expression and they lend support to the concept that in the human cervix the epithelium actively participates in the local immune response.
\end{abstract}

Gastroenterologia 1, Policlinico Umberto 1, Rome

$S$ Fais

F Pallone

Cattedra de Patologia

Ostetrica e

Ginecologica IV

F Delle Fratte

F Mancini

V Cioni

M Guadagno

G Vetrano

Departimento di

Medicina

Sperimentale,

Università di Reggio

Calabria, Catanzaro

F Pallone

Correspondence to:

Dr Stefano Fais, Cattedra di Gastroenterologia 1, Clinica Medica II, Policlinico Umberto I, 00161, Roma, Italy.

Accepted for publication 13 November 1990
There is now convincing evidence that enhanced HLA-DR antigen expression on epithelial cells is a feature of immune mediated inflammatory reactions. ${ }^{1-10}$ In health and disease this expression plays a crucial part in the immunological homeostasis of different organs and tissues. ${ }^{11-15}$ HLA-DR is also associated with neoplastic transformation in different organs. ${ }^{910}$ In the human cervical squamous epithelium HLA-DR antigens are present during viral infection and carcinoma but absent in health. ${ }^{16}$ In contrast, HLA-DR antigens are present in normal human endometrial epithelium; they can also be induced in vitro by exposure to interferon gamma. ${ }^{1718}$

The most potent inducer of HLA-DR antigens on cells of different lineages is interferon gamma, ${ }^{19}$ mostly produced by activated $T$ lymphocytes. ${ }^{20}$ In other disease states the epithelial expression of HLA-DR antigens has been shown in vivo to depend on activation of the local immune system ${ }^{6}$ and the formation of autologous $\mathrm{T}$ cell clones. ${ }^{21} \mathrm{It}$ is therefore conceivable that in human cervical epithelium the expression of HLA-DR antigens is related to the state of activation of the intraepithelial lymphocytes.

The purpose of this study was to investigate the association between the expression of HLA-DR antigens on cervical epithelium and the local immune state of activation in colposcopically obtained biopsy specimens from patients with histologically documented wart virus infection and from controls.

\section{Methods}

Tissue samples were obtained from 36 subjects undergoing colposcopy. Cytological and histological analyses of punch biopsy specimens were performed. There were 10 subjects with normal colposcopic, cytological, and histological appearances, 12 with evidence of mixed epithelial non-viral disease (MENVD), and 14 with wart virus infection.

Diagnosis of wart virus infection was based on the evidence of flat condyloma. Flat condyloma appeared at colposcopy after treatment of the cervix with acetic acid as raised areas (outside the transformation zone) of shiny, white epithelium with a rough surface and with a punctation or mosaic-like vascular pattern. The diagnosis was confirmed in all 14 cases by histology and cytology, showing koilocytic cells and dyskeratotic cells without evidence of dysplasia. ${ }^{22-25}$

Tissue samples were oriented, embedded in Tissue Tek OCT compound (Miles Scientific, USA), snap frozen in liquid nitrogen, and stored at $-80^{\circ} \mathrm{C}$ until used.

At least six frozen sections, $5 \mu \mathrm{m}$ thick, for each specimen were cut on a cryostat, air dried, and fixed in absolute ethanol for 10 minutes at $4^{\circ} \mathrm{C}$. Frozen sections were then stained by an indirect immunofluorescence technique, as previously described. ${ }^{6}$ Briefly, contiguous sections for each specimen were stained for HLADR and IL-2R and incubated with the optimal dilutions of each of the monoclonal antibodies listed below for one hour at $4^{\circ} \mathrm{C}$. Additional sections were incubated with the OKT3 monoclonal antibody. Sections were then washed twice with PBS and incubated with a fluorescein isothiocyanate-conjugated goat-antimouse antibody for 30 minutes at room temperature. Sections were then washed three 


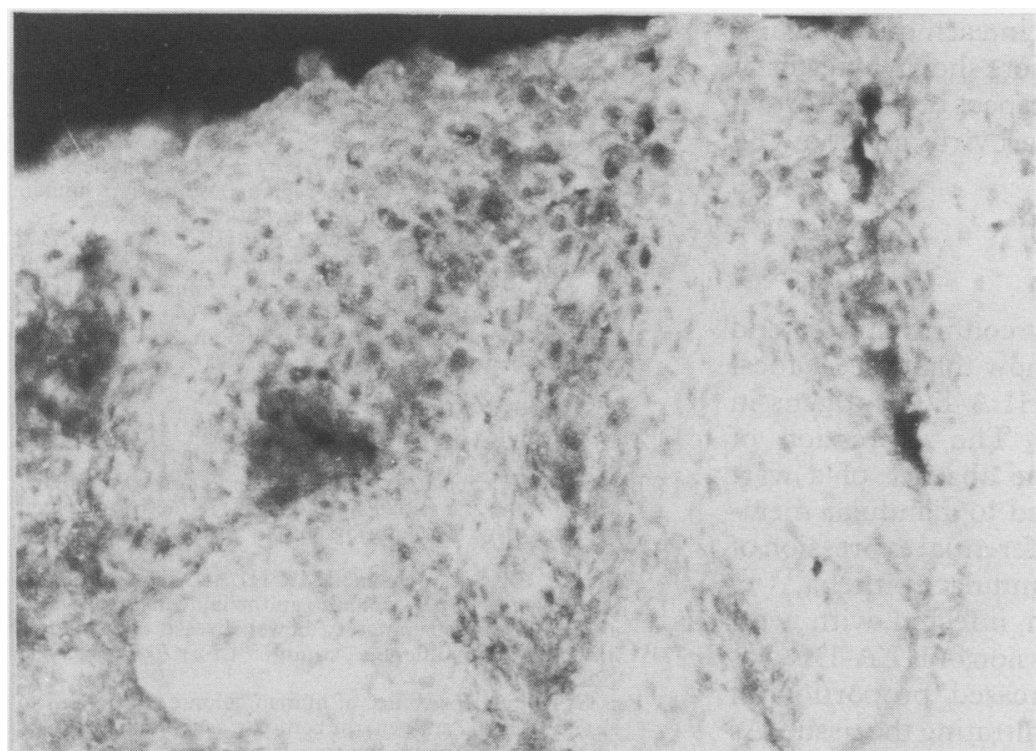

Figure 1 Cryostat section of cervical epithelium infected with wart virus showing strong immunfluorescence staining for $H L A-D R$.

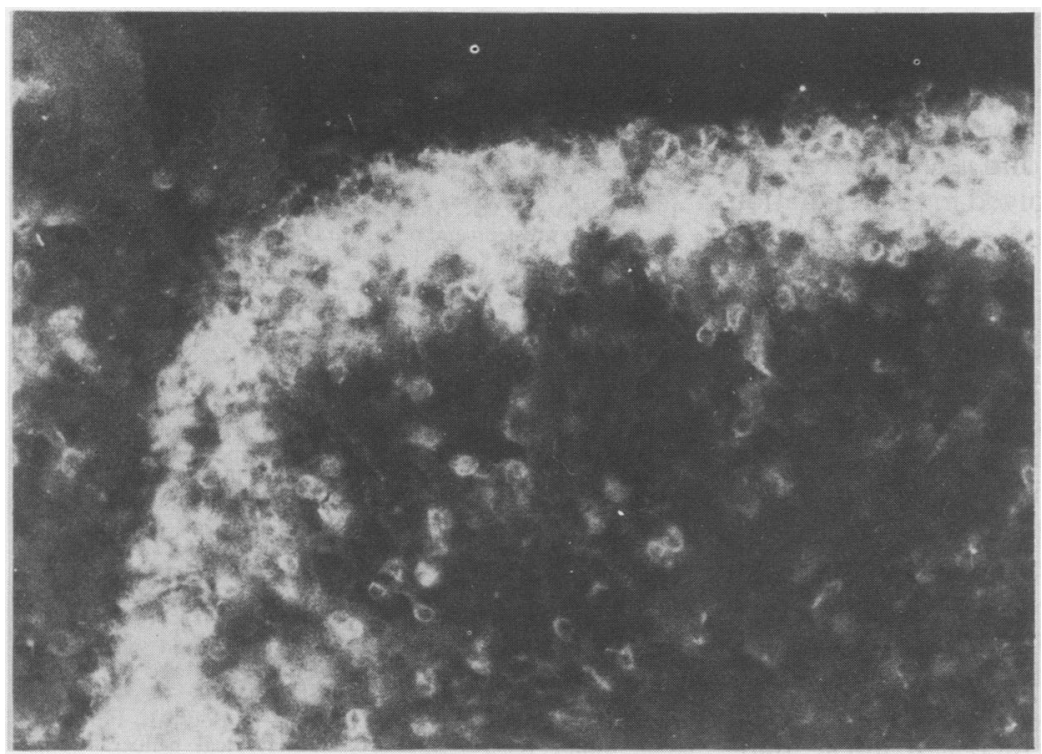

Figure 2 Cryostat section of cervical epithelium infected with wart virus showing an impressive number of mononuclear cells stained for IL-2R.

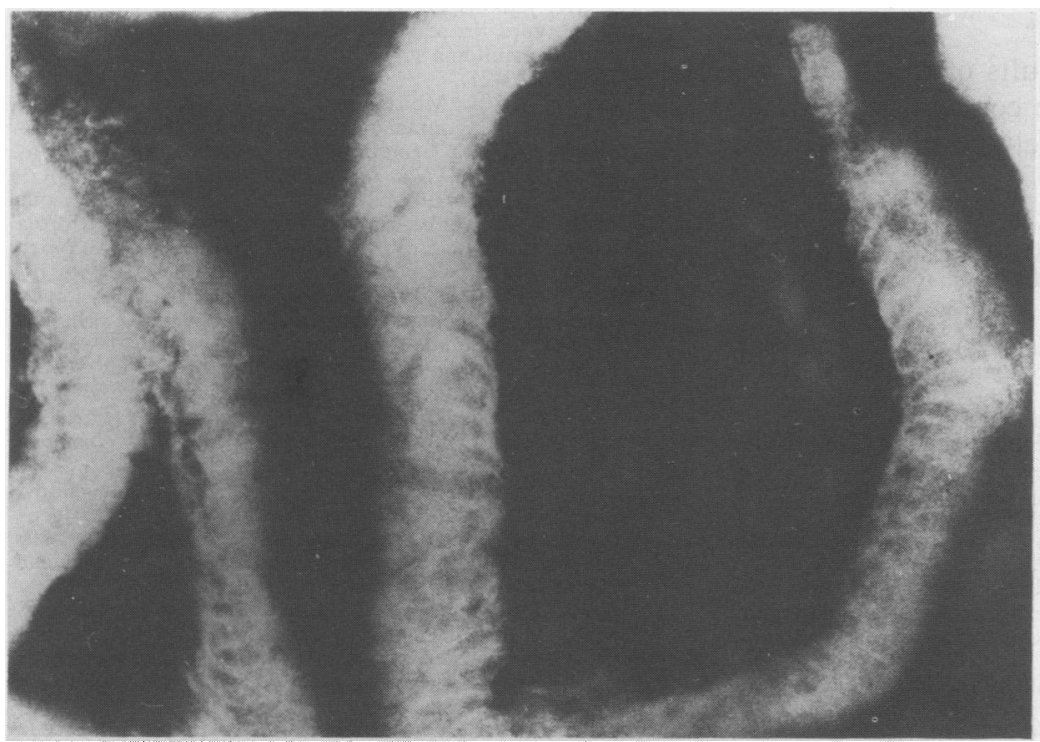

Figure 3 Cryostat section of an area of glandular metaplasia from a non-virally infected cervical epithelium showing intensive diffuse staining of glandular cells for $H L A-D R$. times in PBS and the slides examined using a Leitz Laborlux 12 fluorescence microscope.

Antisera comprised the following: monoclonal antibodies - directed against nonpolymorphic determinants of the HLA-DR molecules included OKIal (Ortho-mune, USA) (diluted 1 in 10) and the anti-DR (clone L243, Becton-Dickinson, USA) (diluted 1 in 10); anti-IL-2 receptor including anti-IL-2R (Becton-Dickinson, USA) (undiluted) and the OKT26a (anti-Tac, Ortho-mune, USA) (undiluted); a pan-T (CD3) monoclonal antibody (OKT3, Ortho-mune, USA).

A FITC-conjugated goat-antimouse immunoglobulin (Becton-Dickinson, USA) (diluted 1 in 30 ) was used as a second layer antibody.

The IL-2R and the OKT3 positive cells per high power field were quantitated in contigous sections stained with haematoxylin and eosin of each case by counting the percentage of positive cells in at least 100 mononuclear cells in a minimum of 10 high power fields.

The Wilcoxon rank sum test was used for the comparison of results in the different groups. Results were expressed as mean (SEM) and range.

\section{Results}

NORMAL CERVICAL EPITHELIUM (NCE)

No HLA-DR staining was detected in normal cervical squamous epithelium with both the antibodies used. No or few IL-2R (mean (SEM): 0.8 (0.6); range:0-2) positive cells were found in the contiguous sections. The percentage of OKT3 positive cells was 86 (9), range: $76-89 \%$.

\section{WART VIRUS INFECTION}

HLA-DR expression in epithelial cells was seen in six out of the 14 samples of wart virus infection. The pattern of fluorescence was focal, but strong and diffuse, to the whole epithelial layer (fig 1). In the six samples with an HLADR positive epithelium the numbers of IL-2R positive cells in the lamina propria were increased ranging between 75 and $90 \%$ (84 (4)) ( $\mathrm{p}<0.001$, with respect to normal controls, cases of mixed epithelial non-viral disease, and wart virus infection without epithelial HLADR expression) (fig 2). In the eight cases of wart virus infection negative for HLA-DR the percentage of IL-2R positive cells did not differ from that of the control group (1.1 (0.7), range 0-2).

In all the cases of wart virus infection the percentage of the OKT3 positive cells did not differ from that of the control group (88 (6), range 80-92).

MIXED EPITHELIAL NON VIRAL DISEASE (MENVD) HLA-DR expression in cervical epithelium was observed in two out of 12 patients with MENVD and the positivity was observed only when glandular metaplasia was present (fig 3). Only a few or no IL-2R positive cells were observed in this group of patients $(0.9(0.6)$, range 0-2) and in two cases with glandular metaplastic epithelium positive for HLA-DR 
(one IL-2R positive cells in each case). Again, no statistical differences were shown in terms of OKT 3 positive cells in respect of both normal controls and those with wart virus infection (85 (7), range 78-90)

\section{Discussion}

The results of this study confirm and extend previous reports which show that there is focal epithelial expression of HLA-DR antigens in wart virus infection. ${ }^{1626}$ The expression of HLA-DR antigens in the absence of a wart virus infection was limited to glandular metaplasia, confirming the preferential expression of HLA-DR antigens by glandular epithelia. ${ }^{36717}$

In cervical epithelium infected with wart virus the enhanced expression of HLA-DR was related to a highly increased proportion of activated lymphocytes infiltrating the tissue. As shown by others, ${ }^{27}$ we found that in both normal and infected cervix intraepithelial lymphocytes were predominantly $\mathrm{T}$ lymphocytes. These findings add support to the hypothesis that epithelial cells bearing HLA-DR are antigen presenting cells which interact with $T$ lymphocytes as targets. ${ }^{21}$ Activated $\mathrm{T}$ cells are able to synthesise in vivo and release interferon gamma; they are also involved in the regulation of HLA-DR expression on cells. ${ }^{192-32}$ Thus in the cervical epithelium of patients infected with wart virus activated $T$ cells may regulate, via the release of interferon gamma, the expression of HLA-DR antigens on epithelial cells. In turn, HLA-DR positive epithelial cells may operate as classic antigen-presenting cells locally activating lymphocytes and inducing specific $\mathrm{T}$ cell clones.

We have shown that the enhanced epithelial HLA-DR expression was restricted to the cervices infected with wart virus. As DNA and RNA viruses modulate major histocompatibility complex (MHC) molecule expression in various virus-transformed cell lines, inappropriate HLA-DR expression on the cervical epithelium of these patients may be associated with wart virus, as suggested for other viruses in other disease states. ${ }^{33-36}$

In conclusion, the results of this investigation lend support to the concept that human cervical epithelium actively participates in the local immune response.

We gratefully acknowledge Mr Mario Termine for photographic assistance and Miss Alessandra Piconi for secretarial help.

1 Wiman K, Curman B, Forsum U, et al. Occurrence of I antigens on tissue of non-lymphoid origin. Nature 1978;276:711-3.

2 Natali PG, De Martino C, Quaranta V, et al. Expression of Ia-like antigens in normal human non-lymphoid tissues. Transplantation 1981;31:75-8.

3 Hanafusa T, Pujol-Borrel R, Chiovato L, Russel RCG, Doniach D, Bottazzo GF. Aberrant expression of HLADR antigen on thyrocytes in Grave's disease: relevance for autoimmunity. Lancet 1983;ii:1111-5.

4 Bottazzo GF, Pujol-Borrell R, Hanafusa T, Feldmann M. Role of aberrant HLA-DR expression and antigen presentation in induction of endocrine autoimmunity: Lancet 1983;ii:1115-9.

5 Barclay AN, Mason DW. Induction of Ia antigens in rat epidermal cells and gut epithelium by immunological epidermal cells and gut epithelium by

6 Fais S, Pallone F, Squarcia O, et al. HLA-DR antigens on colonic epithelial cells: I. Relation to the state of activation of lamina propria lymphocytes and to the epithelial of lamina propria lymphocytes and to the epithelial expression of oth

7 Arnaud-Battandier F, Cerf-Bensussan N, Amsellem R, Schmitz J. Increased HLA-DR expression by enterocytes in children with coeliac disease. Gastroenterology 1986;91:1206-12.

8 Franco A, Barnaba V, Natali P, Balsano C, Musca A, Balsano F. Expression of class I and class II Major Histocompatibility Complex Antigens on human hepatocytes. Hepatology 1988;8:499-54.

9 Ghosh AK, Moore M, Street AJ, Howat JMT, Schofield PF Expression of HLA-D sub-region products on human colorectal carcinoma. Int J Cancer 1986;38:459-64.

10 Houghton AN, Thompson TM, Gross HF, Old LJ. Surface antigens of melanoma and melanocytes. Specificity of induction of Ia antigens by human gamma-interferon. Exp Med 1984;160:255-69.

11 Londei M, Lamb JR, Bottazzo GF, Feldman M. Epithelial cells expressing aberrant MHC class II determinants can present antigen to cloned human $T$ cells. Nature 1984;312:639-41.

12 Mayer L, Shlien R. Evidence for function of Ia molecules on gut epithelial cells in man. J Exp Med 1987;166:1471-83.

13 Bland PW, Warren LG. Antigen presentation by epithelia cells of the rat small intestine. I. Kinetics, antigen specificity and blocking by anti-Ia antisera. Immunology 1986;58:1-7.

14 Pallone F, Fais S, Capobianchi MR. HLA-D region antigens on isolated human colonic epithelial cells: enhanced expression in inflammatory bowel disease and in vitro induction by different stimuli. Clin Exp Immunol $1988 ; 74: 75-9$

15 Fais S, Pallone F. Ability of human colonic epithelium to express the 4F2 antigen, the common acute lymphoblastic leukemia antigen and the transferrin receptor. Gastroenterology 1989;97:1435-41.

16 Morris HB, Gatter KC, Pulford K, et al. Cervical wart virus infection, intraepithelial neoplasia and carcinoma; an immunohistological study using a panel of monoclona antibodies. Br J Ostet Gynaecol 1983;90:1069-81.

17 Tabibzadeh SS, Bettica A, Gerber MA. Variable expressio of Ia antigens in human endometrium and in chronic endometritis. J Clin Pathol 1986;86:153-60

18 Tabibzadeh SS, Gerber MA, Satyaswaroop PG. Induction of HLA-DR antigen expression in human epithelial cells in vitro by recombinant gamma-interferon. Am J Pathol 1986;125:90-6.

19 Capobianchi MR, Ameglio F, Tosi R, Dolei A. Difference in the expression and release of DR, BR and DO molecules in human cells treated with recombinant interferon gamma: human cells treated with recombinant interferon gamma: comparisor.

20 Kasahara T, Hooks JJ, Dougherty SF, Oppenheim JJ Interleukin 2-mediated immune interferon (IFN-gamma) production by human $\mathrm{T}$ cells and $\mathrm{T}$ cells subsets. Immunol 1983;130:1784-9.

21 Londei M, Bottazzo GF, Feldmann M. Human T cell clones from autoimmune thyroid glands: specific recognition of autologous thyroid cells. Science 1985;228:85-9.

22 Meisels A, Fortin R. Condylomatous lesions of the cervix and vagina. I. Cytological patterns. Acta Cytol 1976;20:505-9.

23 Meisels A, Fortin R, Roy M. Condylomatous lesions of the cervix. I. Cytologic, colposcopic and histopatological cervix. I. Cytologic, colposcopic
study. Acta Cytol 1977;21:379-89.

24 Paavonen J. Colposcopic findings associated with human papillomavirus infection of the vagina and the cervix. papillomavirus infection of the va

25 Reid R, Stanhope CR, Herschman B, Booth E, Phibbs G Smith J. Genital warts and cervical cancer. Cancer 1982;50:191-202.

26 Roncalli M, Sideri M, Giè P, Servida E. Immunophenotypic analysis of the transformation zone of human cervix. $L a b$ Invest 1988;58:141-9.

27 Tay SK, Jenkins D, Maddox P, Singer A. Lymphocytes phenotypes in cervical intraepithelial neoplasia and human papilloma virus infection. BrJ Obstet Gynaecol 1987;94:16-21.

28 Robinson BWS, McLemore TL, Crystal RG. Gamma interferon is spontaneously released by alveolar macrophages and lung $\mathrm{T}$ lumphocytes in patients with pulmonphages and lung T lumphocytes in patients with

29 Fais S, Capobianchi MR, Pallone F, et al. Spontaneous release of interferon-gamma by intestinal lamina propria lymphocytes in Crohn's disease. Kinetics of in vitro lymphocytes in Crohn's disease. Kinetics of in vitro
response to IFN-gamma inducers. Gut 1991; (in press).

30 Pober JS, Gimbrone MA, Cotran RS, et al. Ia expression by vascular endothelium is inducible by activated $T$ cells and by human gamma interferon. $J$ Exp Med 1983;157 $1339-53$.

31 Todd I, Pujol Borrel R, Hammond LJ, Bottazzo GF Feldmann $M$. Interferon gamma induces HLA-DR expression in thyroid epithelium. Clin Exp Immunol 1985;61:265-73.

32 Herlyn M, Guerry D, Koprosky H. Recombinant gamma interferon induces changes and shedding of antigens associated with normal human melanocytes,

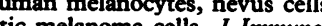
1985;134:4226-30.

33 Albino AP, Houghton AN, Eisinger M, et al. Class II histocompatibility antigen expression in human melanocytes transformed by Harvey murine sarcoma virus cya-MSV) and Kirsten MSV retrovirus. J Exp Med 1986;164:1710-22.

34 Massa PT, Dorries R, ter Meulen V. Viral particles induce Ia expression on astrocytes. Nature 1986;320:543-6.

35 Suciu-Foca N, Rubistein P, Popovic M, Gallo RC, King DW. Reactivity of HTLV-transformed human T-cel lines to MHC class II antigens. Nature 1984;312:275-7.

36 Ciampolillo A, Marini V, Mirakian R, et al. Retrovirus-like sequences in Graves's disease: implications for human autoimmunity. Lancet 1989;i:1096-9. 